\title{
СЕБЕР ТАТАРЛАРЫННАН БЕРЕНЧЕ РОМАН ЯЗУЧЫ ЯКУБ ЗӘНКИЕВ: ТОРМЫШЫ ҺӘМ ИЖАТЫ
}

Flera SEYFULINA*

\begin{abstract}
Аннотация
Мәкалә себер жирлегендә яшәп ижат итүче прозаик, “Иртеш таңнары”, “Ялкында өтелгән мәхәббәт” романнары авторы Якуб Зәнкиевның тууына 100 уңаеннан язылды. Әлеге хезмәттә язучының тормышы һәм әдәбиятка килү юлы өйрәнелә. Прозаның олы жанрында язылган үзенчәлекле әсәрләрендә себер татарларының XX гасырның беренче яртысындагы тормышы Русия тарихында булган катлаулы вакыйгалар кысасында, аның бер өлеше буларак тәкъдим ителә. Әсәрләрендә себердә яшәүче татар халкының горефгадәтләре, психологик портреты, яшәешенең мораль-этик кануннары, әйләнә-тирәгә, аеруча табигатькә үзгә мөнәсәбәте сюжет үзәгендә тора. Халык ижаты жәүһәрләре, төбәкнең бай тарихы һәм шәхесләре, кабатланмас мифологиясе романнарында дөнья сурәтен баетып киләләр. Аерым географик жирлектә язылып, шушы төбәк әдәбиятына гына хас булган уникаль сыйфатлар белән характерланган әсәрләр гомуммилли әдәби мирасның кабатланмас, үзенчәлекле бер өлеше буларак бәяләнә. Ижатының бүгенге көндә өйрәнелү дәрәжәсе ачыклана.
\end{abstract}

Төп Төшенчәләр: Татар Әдәбияты Тарихы, Милли Әдәбият, Якуб Зәнкиев, Әдәбиятта Дөнья Сурәте, Халык Тарихы.

\section{SIBBIRYA TATARLARININ İLK ROMANCISI YAKUB ZENKIYEV: HAYATI VE ESERLERI \\ Özet}

Bu makale, Sibirya bölgesinde yaşayıp eser veren romancı, "İrtı̌ş Tannarı", "Yalkında Ötı̆lgen Mexebbet" romanlarının yazarı Yakub Zenkiyev'in doğumunun 100. yılı münasebetiyle yazıldı. Çalışmada yazarın hayatı ve edebiyat dünyasına dâhil olması ele alınmıştır. Nesrin büyük türünde yazılan özellikli eserlerinde Sibirya Tatarlarının 20. yüzyılın ilk yarısındaki hayatı Rusya tarihinde meydana gelen karmaşı olaylar çerçevesinde, bunun bir bölümü olarak takdim edilmektedir. Yakub Zenkiyev'in eserlerinde Sibirya'da yaşayan Tatar halkının örfâdetleri, psikolojik portresi, yaşamlarının moral-etik kanunları, çevreye, ayrıca tabiata farklı münasebetleri çalışmanın temelini oluşturmaktadır. Halk edebiyatı cevherleri, bölgenin zengin tarihi ve şahısları, eşsiz mitolojisi romanlarında dünya görünümünü zenginleştirmektedir. Farklı bir coğrafi bölgede yazılıp bu bölge edebiyatına has olan benzersiz sıfatlarla donatılan eserler millî edebî mirasın eşsiz, özellikli bir parçası olarak değer kazanmaktadır. Ayrıca Yakub Zenkiyev'in eserlerinin günümüzde ne kadar ele alındığı açıklanmaktadır.

Anahtar Kelimeler: Tatar Edebiyatı Tarihi, Millî Edebiyat, Yakup Zenkiyev, Edebiyatta Dünya Görünümü, Halk Tarihi.

\footnotetext{
* Prof. Dr., Kazan Federal Üniversitesi, Tataristan-Rusya. El-mek: fsaifulina@mail.ru
} 


\title{
THE FIRST NOVELIST OF SIBERIAN TATARS JAKUB ZANKIYEV: HIS LIFE AND WORKS
}

\begin{abstract}
The article is devoted to the centenary of the life and work of writer Jakub Zankiyev. His work was consecrated about his life about creative journey and written in the genre of prose, covering the life of the Siberian Tatars in the first half of the 20th century, as well as difficult events in the history of Russia. In the basis of the work formed the features of traditions, customs and a psychological portrait of the Tatar people. In the story reflected the essence of the environment and respect for nature. His novels illuminates unique world of mythology. In this article the level of study of the writer and today.
\end{abstract}

Key Words: History Of Tatar Literature, National Literature, Jakub Zankiyev, A Reflection Of The World In Literature, The History Of The People.

Агымдагы елның 6 апрелендә Татарстанның Габдулла Тукай исемендәге премиясе лауреаты, язучы Якуб Камали улы Зәнкиевнын тууына 100 ел тулу билгеләп үтелә. Гасыр башындагы давыллы, даулы елларда дөньяга аваз салган булачак язучы илебез белән бергә катлаулы тормыш юлы уза.

XX гасыр ахыры Русиядә яшәүче hәрбер халыкның үз әдәбияты, мәдәнияты, килеп чыгышы həм үсешенә игътибары артуы белән характерлана. Совет чорында зур югалтуларга дучар булган халыклар үзенең тарихи тамырларын эзли, югалткан горефгадәтләрен, йолаларын, динен кайтарырга, шуның белән халыкны милләт буларак саклап калырга тырыша. Гасырлар буенча тупланган гореф-гадәт, йолаларны кире кайтаруда язма әдәбиятның да роле бик зур. "Гомуммилли әдәбият галимнәр тарафыннан жентекле өйрәнелгән булса, аерым төбәкләрдә ижат ителгән әдәбиятларның үзенчәлекләрен тикшерY, нигездә, XX гасырның соңгы чирегендә актуальләште. Әдәби белем биру системасында региональ компонентка йөз тоту, бу юнәлешкә игьтибар көчәю, әдәби әсәргә яңача якын килү таләбе куелу - барысы бу юнәлешнең әһәмиятен тагын да арттыра”. (Талипова-Сәйфулина, 2016: 72)

Бу жәхәттән караганда, Якуб Зәнкиев - себер татарлары тормышы турында тарихи нигездә, киң эпик пландагы романнар язучы буларак әһәмиятле. Аның ижаты да XX гасырның икенче яртысына туры килә.

Төмән өлкәсендә танылган әдәбиятчы-галим һәм тәнкытьче В.Рогачев “Иртеш таңнары” романының рус телендә чыккан тәржемәсенә кереш сүзендә себер татарлары кебек күп гасырлар буенча $\mathrm{Y}^{3}$ гореф-гадәтләрен, мәдәниятын саклап кала алаган халыкның олы хөрмәткә лаеклы һәм нык нигезле булуына басым ясап болай яза: "Мондый халык рухи үзаңның әдәби елъязмасы буларак үз әдәбиятына лаек. Ләкин тарихи деформацияләр һәм катастрофалар озак вакыт себер татарлары арасыннан профессионал язучылар үсеп чыгуына мөмкинлек бирмәделәр. Бары тик гасырның соңгы чирегендә, Русия өчен авыр реформалар елларында гына алар үзләре турында аваз салдылар". (Рогачев, 1998: 312)

Якуб Камали улы Зәнкиев 1917 елның 6 апрелендә Өркет (Иркутск) каласында туа. Аның бабасы Зәнки - жирсез сарт (Бохара якларыннан Себергә килгән төрки кавем) фәкыйрьлектән интегеп, туган авылын - хәзерге Төмән өлкәсе Тубыл районы Хужайлан авылын ташлап, читкә эш эзләп китә. Егерме биш ел байларда ямщик булып Тубыл, Ом, Өркет калалары арасында йөк ташый. Олаучылар Тубылдан кыйммәтле тире-пушнина, замш бияләйләр алып китеп, Өркеттән кытай чәе, ефәк, мануфактура төяп кайтканнар. Кайчагында юлга бишәр йөз ат чыгып китә торган булган, “сәяхәтләре” еллар буе дәвам иткән. Байкал күле тирәсендә тимер юл төзелә башлагач, Зәнки абзый шунда биш ел таш 
каерган. Улы Камалине да үз янына алдырган һәм аны камыт тегүче итеп эшкә урнаштырган.

Якубның әнисе Закирәбану Татарстанның Норлат районы Әрә авылыннан Вәлит мәзин кызы булган. Алар гаиләсе дә Өркет ягына бәхет эзләп килеп чыккан, шунда Камали белән танышып, гаилә корганнар, тиздән аларның беренче балалары - Якуб дөньяга килгән. Улларына бер яшь тулганда яшь гаилә ата-аналарының туган туфрагына - күчеп кайта. Булачак язучының балачагы, яшьлек еллары шунда үтә. (Якубка бары 8 яшь, ике сеңелесе - Зәйтүнәгә 5 яшь, Заһидәгә бары сигез генә ай гына булганда әниләре вафат була, балалар бабалары Зәнки һәм абзыйлары Сәләхетдин, аның хатыны Зиннәтбану карамагына калалар).

Гасыр башындагы давыллы, даулы елларда дөньяга аваз салган Якубка катлаулы тормыш юлы узарга туры килә. Башлангыч белемне ул үз авылында ала, мәктәптә беренче адымнарыннан ук укуга зур омтылыш, белем алуга хирыслык күрсәтә. Әлеге авыр, катлаулы елларда үзенә белем алырга ярдәм иткән кешелекле укытучылары Урамаев Мөхәммәтулла, Бекшенев Зиннур, Ильясов Хөсәен, Әхмәтов Ваһап абыйлары, Галиәкбәрова Фатыйма апаларны Якуб ага олыгайган көнендә дә олы хөрмәт һәм рәхмәт белән искә ала иде. Язучының тормышындагы һәм ижатындагы идеалы - мораль, әхлак ягыннан үтә пакъ, үзләрен бөтенләе белән яраткан эшләренә - балалар укытутәрбияләүгә, халыкка, жәмгыятькә хезмәт итүгә багышлаган кешеләр булуы әлеге укытучылары тәэсирендә формалаша. Тобол шәһәрендәге жидеелллык татар крестьян яшьләре мәктәбердә белем алу бәхете (шәһәрнең йөз еллык тарихы булган хәзерге 15 нче номерлы тәрбия эше татарча алып барыла торган мәктәбе) аның киләчәген хәл итә: әлеге мәктәпне тәмамлагач, 17 яшьлек егет туган авылында башлангыч сыйныфлар укытучысы итеп билгеләнә. Соңрак Тоболда педагогия техникумында белем ала, Төмән укытучылар институтының физика-математика факультетын тәмамлый.

Илебез тарихында булып узган икенче Бөтендөнья сугышы булачак язучы язмышында тирән эз калдыра. Ватан өчен изге көрәшкә күтәрелгән кыю кешеләр арасында мөгаллим Якуб Зәнкиев та була. Сугыш елларында ул Себер бригадасы составында 5800 чакрым юл үтә: Львов, Дрезден, Праганы алуда, Висла, Одер елгаларын кичеп, Германия, Польша, Чехословакия жирләрендә барган канлы сугышларда катнаша. Бригада жиңүне Чехословакия жирендә Прагадан ерак түгел урнашкан Вельтруси шәһәрендә каршылый. Бу шәһәрнең иске мәктәбе урынына яңа мәктәп төзү өчен сугышчылар акча жыеп калдырулары, шул акчага төзелгән мәктәпкә “Кызыл Армия" исеме бирелүе хакындаЯкуб ага горурланып искә ала иде. Сугышта күрсәткән батырлыклары өчен Я.Зәнкиев “Кызыл йолдыз”, 1-2 дәрәжә “Ватан сугышы” орденнары, күп кенә медальләр белән бүләкләнә.

Сугыштан кайткач, Төмән өлкәсенең Ялутор районы Аслана мәктәбендә укыту эшләре мөдире, директор булып эшли. 1950 елда Асланадан туган ягына - Хужайлан мәктәбенә директор булып кайта. Тубыл районы мәгариф бүлеге мөдире булып та эшли. 1975 елгача туган мәктәбен житәкли.

Тарихта булган үзгәрешләргә, тормышта туган төрле катлаулы мәсьәләләргә битараф булмавы аны журналист-язучы эшенә алып килә. Якуб абый - заманының катлаулы мәсьәләләренә кагылган 400 гә якын публицистик мәкалә авторы. Әдәби ижат эшенә ул зур тормыш тәжрибәсе туплап, журналистлык эше аша килә, әдәбиятыбызның олы хәзинәләрен үзенчәлекле образлар, әлегә кадәр күренмәгән Себер киңлекләре сурәте белән баета.

Себер жирлегендә формалашкан талантлы журналист, язучы Якуб Зәнкиевны әдәбиятка, беренче чиратта, туган халкы тарихын, аның үзенчәлекле гореф-гадәтләрен, халык авыз ижаты үрнәкләрен язма китап битләрендә теркәп, беркетеп калдыру теләге китерә. Олыгаеп әдәби эшчәнлеккә килгән Якуб ага үзенең аз санлы, ләкин бәрәкәтле 
әсәрләрендә әлеге максатына иреште -халыкның авыз ижаты әсәрләрен, туган туфрагының бай табигатен, шунда туып-үскән замандашының үзенчәлекле йөз-кыяфәтен, дөньяга карашын, холык-фигылен мәңгеләштерде дип әйтә алабыз.

Якуб Зәнкиевның әдәби мирасын өч йөздән артык публицистик мәкаләләре, дистәдән артык хикәяләре, "Иртеш таңнары" исемендә дөнья күргән дилогиясе һәм “Ялкында өтелгән мәхәббәт” романы тәшкил итә. Аның киңкырлы публицистикасын “Казан утлары”, “Сөембикә”, “Мәгариф”, “Татарстан яшьләре”, “Ялкын”; Төмән өлкәсе басмалары - "Тюменская правда", “Тобольская правда" битләрендә татар hәм рус телләрендә басылып килгән очерк, эссе, фельетон, мәкаләлә жанрына караган язмалары төзи. Аларда автор укытучы, мәктәп житәкчесе, Бөек Ватан сугышын кичкән ветеран, ил язмышына битараф булм аган шәхес буларак таныла. Әлеге язмаларында халык башыннан кичкән аерым бер эпоха чагылыш таба. Автор монда үз регионы, ил күләмендә әһәмиятле булган мәсьәләләр, белем бирү торышы, милли мәктәп, киләчәк буынга әхлакый һәм патриотик тәрбия бирү һ.б. бик күп мәсьәләләрне күтәреп чыга; гаилә, намус, вождан, жаваплылык, яшәү мәгънәсе, яхшылык һәм явызлык көрәше кебек төшенчәләргә карата үз фикерләрен яза, ата-бабаларыбыздан мирас булып калган туган телебезне, милли гореф-гадәтләрне, халыкның милли тәрбиясе нигезләрен саклау, янадан тергезү, аларны гаиләдә һәм мәктәптә тәрбия эшенең нигезе итеп кертү кирәклеге хакында борчыла. Ана телен саклау, мәктәпләрдә туган телне укыту, балаларга милли рухта тәрбия бирү мәсьәләләре - Я.Зәнкиевне гомеренең соңгы көннәренәчә борчып килгән сораулар булды; аксакал язучы бу мәсьәләгә карата үзенең фикерен өзеп әйтә алды, битарафларны уяту теләге белән янып яшәде, шул омтылыш аның яшәү мәгънәсенә әверелде. Вакытлы матбугатның милли мәсьәләләрне хәл итүдә, халыкны берләштерүдә, тел һәм мәдәниятне саклауда һәлиткеч роль башкаруына инанган хәлдә, Я. Зәнкиев өлкә татар гәзите “Яңарыш”ның (берече мөхәррире Азат Сәгыйтов) һәр санында диярлек басыла, замана тарафыннан кискен куелган мәсьәләләрдә сабыр акыл белән алтын уртаны табуга ярдәм итәрлек чыгышлар ясый. 1990-2000 еллар арасында Я.Зәнкиевнең милли мәсьәлә хакындагы житди уйлануларын чагылдырган мәкаләләре ул еллардагы өлкәдә барган милли хәрәкәттә катнашучы милләттәшләребез өчен көтеп алынган фикер, милләтебез аксакалының тормыш тәжрибәсен чагылдырган язмалары буларак кабул ителүе дә язучы сүзен тану, олылау, хөрмәт итү чагылышы.

Зәнкиевне киң жәмәгатьчелеккә язучы буларак таныткан әсәре, әлбәттә, “Иртеш таңнары” (Зәнкиев, 1999: 312) романы булды. Язучының үзе өчен әлеге әсәренең дөнья күрүе - күпъеллык ижат хыялларының, ниһаять, тормышка ашуы булса, төбәк өчен олы әдәби вакыйга, гомумтатар әдәбиятында ул яңа тема, Татарстаннан читтә гомер сөрүче татар кавеменең үзенчәлекле дөнья сурәте чагылышы буларак кызыксыну тудырырлык әсәр буларак кабул ителде.

Билгеле бер халык, этносның үзенчәлекле менталитеты чагылышы - милли әдәбиятның төп сыйфатларыннан берсе. Милләтнең психологик портреты, яшәешенең мораль-этик кануннары, әйләнә-тирәгә мөнәсәбәтенең сурәте сүз сәнгатенең үзәгендә тора. Гуманлылык һәм гомумкешелек кыйммәтләрен алга сөрү - татар әдәбиятының төп билгесе. Әлбәттә, тарихи башлангыч мондый әсәрләрнең асылын тәшкил итә. Я. Зәнкиевнең романнарында илебез тарихындагы катлаулы вакыйгалар Себер жирлеге, себер татарлары язмышы аша чагылдырыла, үзенчәлекле геройларның холыкфигыльләре тарихи һәм табигый яшәү шартларында, үзләренә хас гореф-гадәтләре аша ачыла. Аерым детальләр, символлар, кабатланмас образлар галереясы романны татар әдәбияты тарихында авыл прозасына караган бихисап әсәрләр арасында да танылырлык һәм үзенчәлекле итә. Әлеге сыйфатлар язучының икенче зур күләмле әсәре - “Ялкында өтелгән мәхәббәт" (Зәнкиев, 1999: 312) романына да хас.

Әлеге зур эпик полотноларда Төмән жирлегендә гомер итүче халыкның ХХ гасыр башыннан алып, урталарына кадәр булган тормыш панорамасы тудырыла. Я. Зәнкиев 
романнарында этнографик детальләр, халыкның әлеге як табигатенә яраклашып гомер сөрүе, көнкүреш сурәтен чагылдыру аша милли характерлар ачылган. Әсәрләргә әдәби анализ ясау себер татары язучысы тарафыннан тудырылган пространство моделен аңларга юл ачса, мәдәни-тарихи, тарихи-әдәби һәм мифопоэтик контекстларга мөрәжәгать итү исә авторның тормыш картинасын тудыру үзенчәлекләрен аңларга һәм кабул итәргә мөмкинлек бирә.

Үзәгендә дөреслек-хакыйкать эзләүче укытучы образы торуы - әсәрләрнең эчтәлеген язучының үз биографиясенә якын итә. Язучы илебез тарихында булган зур тетрәнүләр вакытында татар халкының язмышын, тормышларын бөек максатларга багышлаган катлаулы язмышлар аша яктыртуга ирешә. Эпик киңлек, зур гомумиләштерүләр, милли-тарихи характердагы мәсьәләләргә мөрәжәгать итү Я. Зәнкиев әсәрләрен Г. Ибраһимовның "Безнең көннәр" (1934), М. Галәүнең “Болганчык еллар" (1976), Ф. Хөснинең “Жәяүле кеше сукмагы” (1957), И. Газиның “Онытылмас еллар" (1949-1966), К. Нәжминең “Язгы жилләр” (1948) кебек танылган татар романнары белән аваздаш итә.

Әлбәттә, һәрбер әдип өчен дә иң әһәмиятлесе - ижатының үз укучысына барып ирешүе, аны дулкынландыруы, уйланырга мәжбур итүе - ягъни битараф калдырмавын аңлау, тою дип ышанып әйтә алабыз. Бу яктан караганда да Якуб ага үзе исән вакытында ук үз эшенең нәтижәсен күрә, тоя алган сирәк язмышка ия булган каләм иясе дип әйтергә мөмкин. Әлеге юбилей уңаеннан язучы ижатының өйрәнелеш дәрәжәсе хакында да зурдан кубып нәтижәләр ясарга жирлек һәм мөмкинлек бар.

Язучы ижатына беренче бәя - “Иртеш таңнары” романы басылып чыккач, “Казан утлары” журналында Гариф Ахунов тарафыннан еллык күзәтү мәкаләсендә урын алды: “Себер ягыннан "Иртеш таңнары” әсәрен язып жибәргән Якуб Зәнкиев күнелдә өмет уята. Роман моңарчы без күрмәгән себер ягы кешеләренең кызыклы образларына бай булуы белән генә түгел, үзенә генә хас, кабатланмас тел үзенчәлекләре, себер чишмәләре төсле яңа агынтысы белән дә игътибарга лаек". (Ахунов, 1989: 186) Ягъни татарның танылган язучысы Я. Зәнкиев ижатының отышлы ягы нидә икәнен әлеге мәкаләдә үк ассызыклый.

“Иртеш таңнары” романының 1988 елда Татарстанда үткәрелгән “Елның иң әйбәт китабы” бәйгесендә М. Мәһдиевнең дә укытучылар тормышына багышлап, жәмгыятьтә аның урыны, абруе, сугыштан соңгы елларда балаларга белем, тәрбия бирүдә ирегетләрнең роле хакында фикер йөртеп язылган “Фронтовиклар” әсәреннән кала икенче урынны яулавы да әлеге әсәрнең күпсанлы укучы тарафыннан яратып укылуы жәмәгатьчелек бәясе буларак кабул ителә ала.

Әлбәттә, әдәбиятның популярлык дәрәжәсен, аның балалар, яшьләр тарафыннан укылуы билгели. Бу яктан караганда, прозаның кече жанрына караган әсәрләре тәрбияви характердагы хикәяләренең һәм беренче романыннан аерым өзекләренең регионның татар этнокультуралы компоненты булган мәктәпләр программаларына кертелүе - уңай һәм файдалы күренеш. Әлбәттә, төбәк әдәбияты - баланы үз жиренең тел байлыгы, әдәби үзенчәлеге, гомумтатар әдәбиятында аның тоткан әһәмиятле урынын аңларга, бәяләргә ярдәм итә.

Язучы ижатын фәнни нигездә өйрәнүнең беренче адымнары регионда дистә еллар дәвамында үткәрелеп килгән “Сөләйманов укулары” фәнни-гамәли конференциясеннән башланды дип әйтсәк, ялгышмабыз дип уйлыйм. XX гасыр ахырында оештырыла башлап, быел 20-нче тапкыр үткәрелә торган әлеге фәнни чарада, әлбәттә, Булат Сөләйманов ижаты белән бергә Якуб Зәнкиевка багышланган мәкаләләр дә шактый басылды. Алар арасында мәктәп укучылары, студентлар, укытучылар тарафыннан язучы ижатының аерым әсәрләренең мәктәптә укытылышы мәсьәләсенә, аларның тәрбияви 
роленә багышланган кечкенә күләмле мәкаләләр дә, әдәбият белгечләре тарафыннан язучы ижатына беренче фәнни бәяләр дә бар. Тубыл дәүләт педагогика институты тарафыннан Зәнкиев шәхесенең үзенә багышланган фәнни-гамәли конференция үткәрелә башлау - язучының үз ижатын өйрәнүгә генә түгел, гомумән, себер татарлары тарихы, теле, мәдәнияте, уку-укыту торышы мәсьәләләрен кабат күтәрү, актуальләштерү, аерым аспектларын өйрәнү юнәлешендә эшне дәвам итү, аның нәтижәләрен конференция мөнбәреннән житкерү мөмкинлеген булдырды. Юбилей уңаеннан әлеге фәнни форумның яңадан оештырылуы да гомерен балаларга багышлагана укытучы-язучы шәхесе алдында баш ию, исемен мәңгеләштерү, ижатын тагын бер кат барлау буларак кабул ителә ала.

Зәнкиев ижаты буенча беренече житди фәнни хезмәт “Атачак таңнар хакына” дип аталган монография (Сәйфуллина, 2004: 104) булды. Әлеге татар телендә бастырылган хезмәт - китап авторының язучы ижатын төрлеяклап өйрәнүе нәтижәсе булып тора. Китап дөнья күргәнче авторының язучы ижаты хакында дистәләрчә коференцияләрдә чыгыш ясавын, мәкаләләренең фәнни журналларда дөнья күрүен дә искә алырга тешле.

Китап, соңрак рус телендә бастырылган “Төмән регионы татар әдәбиятының формалашуы һәм үсеше” (Сайфулина, 2007: 296) монографиясенең бер өлешен тәшкил итеп, язучы ижатына фәнни бәяне рус телле укучыга да житкерү мөмкинлеген булдырды. Әлеге хезмәт исә тиздән авторының “Төмән өлкәсе татар әдәбияты: тарих һәм заман” (Татарская литература, 2008: 374) дип билгеләнгән докторлык эшенең нигезен тәшкил итте һәм хезмәт регион әдәбиятын системалы рәвештә халык авыз ижатыннан башлап бүгенге көндәге торышына кадәр өйрәнүнең логик нәтижәсе булды.

XXI гасырның беренче дистәсе - Тобол педагогия институтының филология факультеты каршында "Россия Федерациясе халыклары телләре (татар теле)" hәм "Россия Федерациясе халыклары әдәбияты (татар әдәбияты)" белгечлекләре буенча докторлык һәм кандидатлык диссертацияләре яклау Советы оешу белән билгеләнә. 20032012 елларда эшләп килгән әлеге Советта шул елларда татар теле, чагыштырма тел белеме һәм татар әдәбиятының аерым аспектларын өйрәнүгә багышланган алты дистәдән артык эшләр тикшерелде һәм уңышлы якланды. Әлеге советта Төмән өлкәсе, ХантыМанси автоном округынан кала, Башкортостан, Оренбург, Татарстан вузларыннан килгән эшләр дә каралды һәм уңышлы яклау үтте. Әлеге шартларда бүгенге фәнни форумда ижаты hәм фәнни эшчәнлеге игътибар үзәгендә торган язучы ижатын өйрәнү мөмкинлеге дә киңәйде.

Я. Зәнкиев ижаты буенча кандидатлык диссертацияләренең беренчеләре 2009 елда якланды. "Якуб Зәнкиевның әдәби-публицистик эшчәнлеге" (Кирамова; 2009: 23) темасына башкарылган кандидатлык диссертациясенең авторы Х.Х. Кирамова Тобол педагогия институтының татар бүлегендә белем алып, эшен мәктәптә балалар укытуга багышлаган шәхес булуы ягыннан да кыйммәтле. Әлеге фәнни эш - язучының публицистика өлкәсенә караган хезмәтләрен туплап, тәфсилләп анализлап язылган хезмәт. Язучы ижатының икенче аспекты - Ташкеева Г.Х. тарафыннан башкарылган "Якуб Зәнкиев романнарында мифологик һәм фольклор мотивлары" дигән хезмәттә өйрәнелде. (Татарская литература, 2008: 23). Фәнни эш авторы язучы прозасында әлеге мотивларның кулланылыш дәрәжәсен, әсәрләренең сюжеты кысаларында урын алган фольклор жанрларының башкарган функцияләрен билгели, әдәбият-халык авыз ижаты бәйләнешләренең тирән тарихына нигезләнеп бәя бирә. "Якуб Зәнкиенең “Иртеш таңнары” романының тарихи нигезе һәм геройларының прототиплары” (Аминов , 2009: 20) темасына К.Т. Аминов тарафыннан якланган хезмәт әсәрнең тарихи нигезләрен, чынбарлыктан алынган геройларын өйрәнүгә багышланса, М.С. Хөснетдинова эше “Я.Зәнкиев ижатында хатын-кыз образлары системасы”н өйрәнүгә багышланган (Татарская литература, 2008: 18). Г. Бабшанова тарафыннан башкарылган “ХX йөз себертатар прозасында шәхес чагылышының әдәби концепциясе” (Бабшанова, 2009: 20) дип 
аталган фәнни хезмәттә өйрәнү объекты буларак региональ проза үрнәкләреннән Я. Зәнкиев һәм Б. Сөләйманов прозасы алынган.

Әлбәттә, Институтыбызда татар бүлеге булган, диссертация советы эшләп килгән әлеге чорда жирле язучыларның ижатын өйрәнүне галимнәребез намус эше дип карады. Татар теле һәм әдәбияты кафедрасының бу юнәлештәге эшчәнлеге татар әдәби регионалистикасын формалаштырды, аны нигезләде һәм нәтижәләрен дә бирүгә иреште. Өлкәнең хөрмәтле тел галимнәре - профессор Х.Ч. Алишина, К.С. Садыковлар тарафыннан язылган мәкаләләр шулай ук Я. Зәнкиев шәхесен ачуга юнәлдерелгән булуы белән характерлана.

Шунысы да кызыклы, Якуб аганың әлеге романы төрек галиме Erdal Şahin тарафыннан да кызыксынып укылган булуы мәгълүм. “Көнбатыш Себер татарларының тормышын чагылдырган беренче роман: Иртеш таңнары” (Хуснутдинова, 2010: 165-171) исемле мәкаләсендә әлеге галим Төрек дөньясына себер татарлары тормышы, этник составы, теле хакында шактый мәгълумәт бирә, әсәрдә урын алган тарихы вакыйгаларга, мисал өчен, туган жирләреннән куылган калмыклар язмышы чагылышына тукталып үтә, романда сурәтләнгән гореф-гадәтләр, бәйрәмнәр, дини йолалар, аерым фольклор үрнәкләренә тукталып, аңлатма бирә. E. Şahin аеруча туй йолаларының, сөннәт туеның әсәрдә чагылышына, яңгыр теләге, боз озату, себер татарларының мөселман халкы буларак кылган гамәлләре сурәтләнешенә аеруча зур игътибар бирә. Шулай ук әсәрдә урын алган риваятьләрдән Ялан авылына нигез салыну, аю баласын имезеп үстергән себер татар хатыны, Күчем хан һәм Сүзге, Алтын Мөгез утыравы хакындагы риваятьләрне дә телгә ала, аларны татар халык ижатының кыйммәтле үрнәкләре буларак бәяли. Халык жырлары, бәетләр үрнәкләрен, мәкаль-әйтемнәрдән мисаллар да китерә. Мәкалә авторы әлеге романны татар әдәбиятының үзенчәлекле бер үрнәге буларак бәяли hәм татар тормышын, тарихын, мәдәниятын күрсәтү ягыннан кыйммәтле булуына басым ясый һәм, нәкъ шушы як әсәрне укучы өчен дә кызыклы итүен билгеләп үтә.

Үз вакытында Якуб ага романнарының рус теленә тәржемә ителүенә дә зур игътибар бирде. Әлбәттә, Русия төбәгендә әсәрләрнең киң аудиториягә житүен тәэмин итү башкача мөмкин дә булмас иде. Шул рәвешле “Иртеш таңнары" (тәрж. Х.Ч.Алишина) да, “Ялкында өтелгән мәхәббәт” (тәр. Н.Ш. Сәйфуллина) романы үз вакытында рус телле аудиториягә дә житкерелде.

“Иртеш таңнары”ның русча тәржемәсенә “В ожидании рассвета” дип аталган кереш мәкаләсендә әдәбият белгече В.Рогачев язучының зур эзләнүләре нәтижәсе булып торган беренче романны хаклы рәвештә “халыкчан-тарихи эпопея” (Занкиев 1998: 8) дип бәяләнде. Әлеге фикер белән тарихчы, танылган шәхес Ю.П. Прибыльский да килеште hәм әлеге хакта "Гуманизм дәресләре" мәкаләсендә язып чыкты. (Прибыльский, 1998: 9). Тобол шәһәренең танылган журналисты Г. Минасьян роман хакында: “Иртеш таңнары” үзенчәлекле тарих дәреслеге ул, әлеге дәреслекне Төмән өлкәсендәге һәрбер мәктәптә өйрәнергә иде. Бу китаптан башка безнең өлкәнең тарихы тулы булмас",- дип билгеләп үтте. (Минасьян, 1998: 29-30)

XX гасыр кебек тормышта, шул исәптән әдәбиятта да барган катлаулы үзгәрешләр вакытында Төмән өлкәсе татар әдәбияты халыкчан реализм юлын алып, укучыны мәдәни-рухи яктан үстерә, үзаңын уяту максатына хезмәт итә, милли тарих белән таныштыру, тәрбия бирү юнәлешен сайлый. Үз әсәрләре аша Зәнкиев сүз остасы булып кына түгел, ә фольклорчы, этнограф, туган якны өйрәнүче буларак та танылды. Монда әдәби дөнья сурәте тудыруның үзенчәлекләре турында фикер алышу өчен киң жирлек бар. Әсәрдә милли менталитет чагылышын, әйләнә-тирә дөньяны кабул итүнең аерым сыйфатларын билгеләү язучының ижат үзенчәлеген ачыклауга юл ача. Я. Зәнкиевның әдәби мирасына игътибар, аның әдәбият галимнәре тарафыннан төрлеяклап киң планда өйрәнелүе дә әлеге үзенчәлекләр белән аңлатыла. 


\section{Әдәбият}

ŞAHIN, E. (2005). Batı Sibirya Tatarlarının Hayatını Konu Edinen İlk Roman: İrtéş Tañnarı (İrtiş Tanları). Türk Dünyası Araştırmaları, S. 159, İstanbul, Aralık, s. 165-171.

АМИНОВ, К. Т. (2009). Историческая основа и прототипы героев романа Якуба Занкиева "Зори Иртыши. Автореф. дис. ... канд. филол. наук. - Тобольск,. $20 \mathrm{c.}$

АХУНОВ, Г. (1989). Бүгенге татар романы. Казан утлары, - №5. - Б. 186.

БАБШАНОВА, Г.Н. (2009). Художественная концепџия личности в прозе сибирско-татарских писателей ХХ века: Занкиев Я.К., Сулейманов Б.В. Автореф. дис. ... канд. филол. наук. - Тобольск,. - 20 с.

ЗАНКИЕВ, Я. (1996). Зори Иртышиа. Книга первая. /Пер. с татарского Н. Сайфуллиной/ Я.Занкиев. - Тюмень: СофтДизайн.

ЗАНКИЕВ, Я. (1998). Зори Иртышаа. Кн. вторая. Тюмень: СофтДизайн,.$232 \mathrm{c}$

ЗӘНКИЕВ, Я. (1984). Иртеш таңнары: роман. Казан: Тат.кит.нәшр., 6716.

ЗӘНКИЕВ, Я. (1988). Иртеш таңңнары: роман. Казан: Тат.кит.нәшр., 286 б.

ЗӘНКИЕВ, Я. (1999). Ялкында өтелгән мәхәббәт: роман. Төмән: Вектор Бук,. - 312 б.

КИРАМОВА, Х. Х. (2009). Литературно-публищистическая деятельность Якуба Занкиева. Автореф. дис. ... канд. филол. наук. - Тобольск,. -23 с.

МИНАСЬЯН, Г.П. (1998). Размышления о романе “Зори Иртыша” и его авторе. Жизнь и творчество педагога и писателя Я.К.Занкиева: материаль обл. науч.-практ. конф. Тобольск, С. 29-33.

ПРИБЫЛЬСКИЙ, Ю. (1998). Уроки гуманизма. Жизнь и творчество педагога и писателя Я.К.Занкиева: материаль обл. науч.-практ. конф. Тобольск, C. 10-13.

РОГАЧЕВ, В. В (1998). Ожидании рассвета. Занкиев Я. Зори Иртыша. Тюмень: СофтДизайн, С.8.

САЙФУЛИНА, Ф. С. (2007). Формирование и развитие татарской литературы Тюменского региона. Тюмень: Вектор Бук,. - 296с.

СӘЙФУЛЛИНА, Ф. С. (2004). Атачак таңнар хакына. Тобольск: Д.И.Менделева ис.ТДПИ,.- 104 б.

ТАЛИПОВА, Г. М., СӘЙФУЛИНА Ф. С. (2016). Себер төбәге татар әдәбиятында дөнья сурәте. Tatarika, C. 72-91.

Татарская литература Тюменского региона: история и современность. Диссертация на соискание ученой степени доктора филологических наук (2008)., Казань, 374 б. 
ТАШКЕЕВА, Г. Х. (2009). Мифологические и фольклорные мотивы в романах Якуба Занкиева. Автореф. дис. ... канд. филол. наук., Тобольск, 23 с.

ХУСНУТДИНОВА, М. С. (2010). Система женских образов в романах Якуба Занкиева. Автореф. дис. ... канд. филол. наук., Тобольск, 18 с. 